\title{
The Paradox of Music Transgressions: Noise as a Libidinal Energy ${ }^{1 *}$
}

LA PARADOJA DE LAS TRANSGRESIONES MUSICALES: EL RUIDO COMO ENERGÍA LIBIDINAL

O PARADOXO DAS TRANSGRESSÕES MUSICAIS: O RUÍDO COMO ENERGIA LIBIDINAL

\section{Lílian Campesato**}

Cuadernos de Música, Artes Visuales y Artes Escénicas

/ Volumen 14 - Número 1 / Enero - Junio de 2019

/ ISSN 1794-6670 / Bogotá, D.C., Colombia / pp. 103-114

Received: 30 April 2018

Accepted: 18 October 2018

Available online: 28 December 2018

doi 10.11144/javeriana.mavae14-1.tpom

* Reflection paper. This text is part of the PHD Thesis "Vidro e Martelo: contradições na estetização do ruído na música" (Glass and Hammer: Contradictions on the Aestheticization of Noise in Music) financed by the Coordination for the Improvement of Higher Education Personnel (CAPES).

** Research Associate at the Research Center on Sonology (NuSom) at University of São Paulo. Brazilian performer, researcher and curator. Master in Music and PHD in Musicology from the University of São Paulo, Brazil. ORCID: 0000-0002-9935-3185

\section{How to cite:}

Campesato, Lílian. 2018. "The Paradox of Music Transgressions: Noise as a Libidinal Energy". Cuadernos de Música, Artes Visuales y Artes Escénicas 14(1): 103-114. http://doi. org/10.11144/javeriana.mavae14-1.tpom 


\section{Abstract}

This paper is part of a broader research project that considers noise as an agent of musical transformation. From this perspective, I reflect on the psychoanalytic concepts of repression and death drive. In this context, these concepts are linked to the process of rejection, acceptance and transgression of some elements that constitute the basis of artistic creation. The relationship between transgression and acceptance of noise can be understood as a dialectical and dynamic process. On the one hand, noise can be understood as a disturbing, undesirable, suppressed and repressed event; on the other hand, it can become something acceptable and desirable when incorporated as an aesthetic element. This oscillatory process of acceptance and rejection may be related to two concepts of Freudian psychoanalytic theory: repression and the death drive. These concepts may help to understand the return of what was repressed, what is to be avoided, and what is perceived as noise, connecting this "return" to the idea of remembering something that has been repressed. By pursuing this parallel between noise and psychoanalysis, I intend to understand the mechanism from which an uncomfortable, noisy and sometimes destructive element becomes crucial to overcome a conservative inertia and thus set in motion a spring that propels the cultural dynamics. Although denoting a paradox, this dynamic allows the incorporation of what is considered to be undesirable and it is an essential operation in the transformative processes of music.

Keywords: noise; aesthetization of noise; repression of noise; death drive; artistic transformation; psychoanalysis.

\section{Resumen}

Este artículo hace parte de un proyecto de investigación más amplio que considera el ruido como un agente de transformación musical. Desde esta perspectiva, hago una reflexión sobre los conceptos psicoanalíticos de represión y pulsión de muerte. En este contexto, estos conceptos están vinculados al proceso de rechazo, aceptación y transgresión de algunos elementos que constituyen la base de la creación artística. La relación entre la transgresión y la aceptación del ruido puede entenderse como un proceso dialéctico y dinámico. Por un lado, el ruido puede entenderse como un evento perturbador, indeseable, suprimido y reprimido; por otro lado, puede convertirse en algo aceptable y deseable cuando se incorpora como un elemento estético. Este proceso oscilatorio de aceptación y rechazo puede estar relacionado con dos conceptos de la teoría psicoanalítica freudiana: la represión y la pulsión de muerte. Estos conceptos pueden ayudar a comprender el regreso de lo que se reprimió, lo que se debe evitar y lo que se percibe como ruido, conectando este "regreso" a la idea de recordar algo que ha sido reprimido. Al hacer este paralelo entre ruido y psicoanálisis, busco comprender el mecanismo por el cual un elemento incómodo, ruidoso y a veces destructivo se vuelve crucial para superar una inercia conservadora y así activar un resorte que impulsa la dinámica cultural. Aunque denota una paradoja, esta dinámica permite la incorporación de lo que se considera indeseable y es una operación esencial en los procesos de transformación de la música.

Palabras clave: ruido; estetización del ruido; represión del ruido; pulsión de muerte; transformación artística; psicoanálisis.

\section{Resumo}

O presente artigo é parte de uma pesquisa mais ampla que considera o ruído como um agente de transformação musical. A partir dessa perspectiva, faço uma reflexão sobre os conceitos psicanalíticos de repressão e pulsão de morte. Neste contexto, estes conceitos estão ligados a um processo de rejeição, aceitação e transgressão de elementos que estão na base da criação artística. A relação entre transgressão e aceitação do ruído pode ser entendida como um processo dialético e dinâmico. Por um lado, o ruído pode ser entendido como um evento perturbador, indesejável, suprimido e reprimido; por outro lado, pode tornar-se algo aceitável e desejável quando é incorporado como um elemento estético. Esse processo oscilatório de aceitação e rejeição pode estar relacionado a dois conceitos da teoria psicanalítica freudiana: repressão e pulsão de morte. Esses conceitos podem ajudar a entender o retorno do que foi reprimido, do que deve ser evitado e que é percebido como ruído, conectando esse "retorno" à ideia de rememoração de algo que foi reprimido. Ao fazer esse paralelo entre o ruído e a psicanálise, busco entender o mecanismo pelo qual um elemento desconfortável, barulhento e às vezes destrutivo se torna crucial para superar uma inércia conservadora e, assim, ativar uma mola que impulsiona a dinâmica cultural. Embora denote um paradoxo, essa dinâmica permite a incorporação do que é considerado indesejável e é uma operação essencial nos processos de transformação da música.

Palavras-chave: ruído; estetização do ruído; repressão do ruído; pulsão de morte; transformação artística; psicanálise. 
This paper is part of broader study conducted for my doctoral thesis, "Vidro e Martelo: contradições na estetização do ruído na música," which intends to study noise as a musical transformation agent. The concept of noise goes beyond its sonorous aspect, establishing itself in a contextual and contingent relationship. In this paper, noise is not defined as a thing in itself, but it comes to fruition as the result of a relationship. Thus, noise takes on a transient aspect and, upon being aestheticized, it undergoes a "silencing" process, i.e., when it is incorporated into music, assimilated and recovered, it loses its blatant nature and ceases to be noise. This process is not established in an uncomplicated way, because it involves the cyclical and paradoxical dynamics of artistic transformations. In this section, I intend to start a debate on this dynamic incorporation of noise-also understood as something disturbing, not desirable, suppressed and repressed-like a resigned, acceptable element. For this purpose, I embrace two concepts from Freud's psychoanalytical theory, repression and death drive, in order to investigate the return of what has been repressed, avoided, and construed as noise. This return is explored from the idea of remembering something repressed. On an aesthetic level, this remembrance connects with the dynamic process of motion within artistic transformations, which points to two seemingly paradoxical situations: the repression of noise (prostration) and its remembrance (drive).

It should be noted that the proposed approximation to psychoanalysis made here occurs just by analogy, in an attempt to diversify and expand the approach to the intricate process of artistic transgressions and the paradoxical relationship between something that, when transgressed, becomes something new, and as a novelty, is likely to be transgressed once again. I do not intend to conduct a psychoanalysis of culture, using Freudian concepts built to approach the subject, nor to use them from a more general and less subjective perspective. Rather, this approximating relationship occurs only metaphorically, but, as a metaphor, it will hopefully help us understand, by similarity, the process that leads to something being transgressed.

\section{REPRESSION OF NOISE}

At the end of the 19th century, neurologist Sigmund Freud introduced psychoanalysis as an activity that, by revealing the early traumas to a patient and making him aware of the circumstances leading to his symptoms, would make his psychological illness vanish away. The patient himself should remember these events or provide hints for the analyst to rebuild them. However, the patient posed resistance; he did not want or was not able to bring up information that would lead to the early trauma and its circumstances. Such resistance could emerge in different ways, such as transference, for instance. However, our concern here is with the connection to something disturbing (noise) that one does not want to (or cannot) recall.

As part of the studies on hysteria, most notably on reactions to and remembrances of traumas, especially those that have been stifled or that are not suitably corresponded, Freud resorts to the concept of repression². Initially, repression was linked to defense neuroses (Freud 1988 [1894]); however, in his later writings, repression is not associated with a conscious defense, but seems to be connected to an unconscious nature. The connection that I seek here is that the same principle that triggers the repression of traumas (according to Freud) is observed in the process that represses actual noise, which has a disturbing nature, 
in the context of artistic creation. This noise is something that hinders the continuance of expected events; it is unexpected, mandatory and subversive. Nevertheless, in the pursuit of stability, of organization for understanding, noise is often repressed or changed into something more palatable and acceptable.

A classic example of this stabilization mechanism is disclosed by the Italian Futurist movement, in which, in a radical and new attempt to effectively incorporate the noise of machinery into musical work, noise had to be subjected to an ordination process; in this case, noisy sounds were tuned, while preserving a recognizable aspect in processes regularly used for musical creation. It is neither obvious nor simple to depict the reception of Russolo's futurist works at the time of their debut, and we cannot say that the "tuning" of noises prevented his music from being "noisy." However, the attempt to minimize the "oddness" brought about by the sounds of the Intonarumori is clear.

Interestingly, in order to explain repression and its process of return, Freud employs an allegory of noise derived from insistence:

Perhaps I can make the process of repression and its necessary relation to the resistance of the patient more concrete by a rough illustration, which I will derive from our present situation. Suppose that here in this hall and in this audience, whose exemplary stillness and attention I cannot sufficiently commend, there is an individual who is creating a disturbance, and, by his ill-bred laughing, talking, by scraping his feet, distracts my attention from my task. I explain that I cannot go on with my lecture under these conditions, and thereupon several strong men among you get up, and, after a short struggle, eject the disturber of the peace from the hall. He is now "repressed," and I can continue my lecture. But in order that the disturbance may not be repeated, in case the man who has just been thrown out attempts to force his way back into the room, the gentlemen who have executed my suggestion take their chairs to the door and establish themselves there as a "resistance," to keep up the repression. Now, if you transfer both locations to the psyche, calling this "consciousness," and the outside the "unconscious," you have a tolerably good illustration of the process of repression. (Freud 2006 [1910], 40)

In this case, the misbehavior of the individual in that situation, which, by convention, required silence, served to distract the attention from the speaker's lecture and from the focus on carrying out his task. This attempt to distract by laughing, talking and scraping his feet was insistently repressed, as it prevented the speaker from continuing with his assignment. However, this process of repression, no matter how strong it was, does not necessarily preclude the return of the disturbance sometime somehow. It is noteworthy that the disturbance often returns exactly when one wants to forget it, as in the case described by Freud:

In the case of a woman of about forty, there was a tic, a peculiar smacking noise which manifested itself whenever she was laboring under any excitement, without any obvious cause. It had its origin in two experiences which had this common element, that she attempted to make no noise, but that by a sort of counter-will this noise broke the stillness. On the first occasion, she had finally after much trouble put her sick child to sleep, and she tried to be very quiet so as not to awaken it. On the second occasion, during a ride with both her children in a thunderstorm, the horses took fright, and she carefully avoided any noise for fear of frightening them still more. (Freud 2006 [1910]) 
There is in noise, therefore, a reactive force, a power that coexists with its own repression as a mechanism that leads to the return of the repressed, as a natural troublemaker that insistently labors until he is remembered. This dynamics that represses a noise does not necessarily seem to be detached from the content causing the disturbance. On the contrary, it may be linked to something hidden, albeit familiar and known.

For Freud, the reactive mechanisms of a trauma can work as connections between the strange and the familiar, that is: "(...) when the reaction is repressed, affection remains linked to remembrance." (Freud and Breuer 1988 [1893], 45)

Likewise, noise connects with psychoanalysis, constituting a paradoxical character between the familiar and the strange, as one can note when it is linked to the concept of anguish:

[...] by the action of repression, the familiar, that which is closer to the subject, becomes foreign - what is most strange to him —and its return is precisely what causes anxiety. The experience of strangeness of the subject opposite to what "should have remained secret and hidden but has come to light" [...] adduces evidence of truth, that is, confirms the close relationship between affection and the return of the repressed. Strangeness does not derive from what is merely new, but rather from what is, at the same time, strange and familiar, long inscribed in the psyche and alienated by means of repression. (Fuks 2001, 3, my translation)

The return of the repressed, whether or not induced by disruptive insistence, motivates the formation of a reactive duplicity: prostration or action. This duplicity can be best illustrated in psychoanalysis by the concepts of depression and anxiety. Depression is configured as a consequence of trauma, prostration, passivity, while anxiety symbolizes an active reaction, an action, as noted in the excerpt below:

[...] anxiety is a noise-originating in drive, which will later motivate repression. It appears,

at this time, as a reaction to the helplessness created by this original cut. Depression, by its turn, is related to the reverse, negative side: passivity and helplessness itself-the blow at the traumatic moment. (Delouya 1998)

Noise, understood in this context as anguish, is what motivates repression. Transferred to an aesthetic level, it can acquire a sort of negative condition: the ugly, unwanted, what one does not want to remember and, therefore, is repressed. Apparently, a kind of duplicity promoted by the movement between passivity and activity constitutes the possible dynamics for the understanding of the process of rejection and acceptance of a given concept or material (musical, artistic). Repression, as is understood here, is a halt, the freezing of a particular concept or conception of music, and the death drive is the force that breaks out of this inertia.

\section{NOISE AND DEATH DRIVE}

In his drive theory (2011, 37-38), Sigmund Freud circumscribed two apparently antagonistic drives or instincts: Eros as a sex drive that tends to the preservation of life, and Thanatos as the death drive (sexual or aggressive) that would lead to segregation of all that is alive, to destruction. Although they seem to be contrary conceptions, the life 
drive and death drive are connected, merged, and where there is a life drive, there is also a death drive, both acting in conjunction. This dynamic of drives is governed, according to Freud, by the complementary principles of pleasure-displeasure, which are driven by the demands of libido.

The death drive as a destructive force described by Freud can be analogically understood as a driving force that triggers a reaction, a disturbance knocking at the door, noise. Psychoanalyst Luiz Alfredo Garcia-Roza (2004 [1990]), in his writing O mal radical em Freud (The Radical Evil in Freud), points out that the death drive is what

[...] prevents the repetition of the same, that is, the permanence of totalities, giving rise to the emergence of new forms by disjuncture. It is, therefore, creative and not conservative, since it imposes new beginnings instead of reproducing the "same". True death-the death of desire, of difference-takes place as an effect of Eros, and not of the death drive. (GarciaRoza 2004 [1990], 137)

Although stemming from a destructive force, the death drive does not necessarily imply a negative or nihilistic attitude. In Civilization and Its Discontents, Freud (2010 [1930]) presents the theory that culture produces uneasiness in man, since there is an insurmountable antagonism between instinctual demands and civilization. Thus, for the common good of society, the individual is sacrificed: For civilization to be able to flourish, man has to pay the price by relinquishing his instinctual satisfaction. This is a movement of desingularization of the individual, because individual desire is repressed in favor of a greater good for everyone.

At this point, Freud presents the conflict of a subject who, in seeking to satisfy his instinctual needs, may not be linked to the set of forces that make up repression, such as morality, shame, and disgust. However, drives may play a key role in this process, especially the death drive, as Garcia-Roza (2004 [1990]) points out:

[...] to the extent that the death drive is conceived as a destructive power, we can think of it acting disjunctively and preventing the perpetuation of forms or associations formed by Eros. Freud tells us (in The Uneasiness in Culture) that culture is at the service of Eros, who wants to bring together individuals in increasingly comprehensive totalities, until the formation of a large totality that is humanity. From the uniqueness of the individual to the totality of humanity, we would have an increasing indifferentiation. However, if we understand desire as pure difference, the design of Eros would be the elimination of difference and, therefore, of desire, in a final indifferentiation that is humanity. (Garcia-Roza 2004 [1990], 136)

Based on this idea, I can suggest a connection between death drive and noise. Perhaps there exists in noise an uncontrollable life force that establishes a separation or disruption of a known or rather commonly proposed context. Noise can take a role that disrupts a common shared context, moving towards singularity, difference. Would noise have such power, that of disrupting "totalities"? Or could noise consist of something familiar, intimate, that is, recognizable, that one wants to forget? Is there a destructive force in noise that would prevent the perpetuation of sameness, as suggested by Garcia-Roza in defining the death drive? These are complex questions to which I do not intend to answer; I just want to use them as metaphors of the power that noise may represent ${ }^{3}$. 
According to Freud (2010 [1930]), sublimation is one of the destinations of drive, a kind of channeling of this force toward artistic satisfaction, for example, as an outlet and escape from the helplessness and anguish of loneliness. This relationship between art and a subjective level arising from desire evokes Bernard Stiegler's (2007) attempt to highlight the mechanism of social movement and transformation: "Freud showed it extraordinarily well: art is ultimately what allows, somehow, the sublimation of desire, [...] and, then, the socialization of individual sexual desire transformed into social dynamics" (Stiegler 2007, 61).

In an attempt to map this process and identify art works as something that enables openness to the libidinal desire loop, Bernard Stiegler (2007) diagnoses the noxious effects of manipulating desire and its desingularization. Desire, according to Stiegler, cannot be manufactured, because it can only be unique. Despite this impossibility, since it results from the founding "libidinal energy" (Freud), individual desire "[...] can be, however, manipulated, and in being manipulated, it may be depleted. Therefore, it is conditioning that replaces desire, and this is what actually causes gregarious consumerism" (Stiegler 2007, 28). For Stiegler, there is an attempt to eliminate any "defect" in cultural capitalism, and this attempt has evidenced a characteristic of modern society since the 19th century: "the need, for capitalism, to standardize behaviors in order to make individuals adopt standard objects serially produced, where behaviors are clearly required to be standard themselves and serially induced, or even, actually, produced" (Stiegler 2007, 22). In other words, the mass production or standardization of behaviors eventually annuls the individual and suffocates desire, which is essentially unique. It is as though nothing could be different from what already exits, and desire is imprisoned inside the general libidinal economy of society.

The "defect" to which Stiegler refers is what I intend to indicate here as noise, what is avoided, what does not fit standards, either industrial, commercial or social. A defect is what does not fit the acceptable; it escapes this category, mustering, in its core, the power to differentiate. There is an interesting way to think about a defect, based on the French word for it (défaut), which Stiegler attentively explores:

What is interesting to me about the word "defect" (défaut) is that it contains "it is necessary"

(il faut). A defect (défaut) is not the same thing as a lack (manque). One can revert a defect (défaut) to "it is necessary" (il faut), what I call the need of defect (défaut). (Stiegler 2007, 22)

This need is what I refer to in a previous text ${ }^{4}$ as the "dialectics of noise," pointing out how important it is to get out of the stagnation caused by maintaining a cycle that is closed in itself. This looping dynamic carries a trend towards indifferentiation, by repeating patterns, and the defect, in this case understood as noise, may take on the major role of destabilizing a general order and potentially exist within the very dynamic of situations. A defect may be what is most grotesque and undesirable. That is to say, grotesque is that which is necessary and, at the same time, what one wants to avoid, and the death drive is the force that carries the possibility of breaking the loop and exiting this inertia.

Here I also establish a relation with the body of text-poems extracted from a radio broadcast titled "To Have Done with the Judgment of God," performed by Antonin Artaud (19471948 ) as the author and narrator and some of his friends (Roger Blin, Marie Casarès, and Paule Thévenin) $)^{5}$ In these texts, created to be aired on the radio, there is an approximation, in a rough fashion, of the dialectics of noise and the disruptive force necessary for moving. 
Below is a small excerpt from a text by Artaud $(1988,559-560)$ that illustrates the connection I seek:

\author{
THE PURSUIT OF FECALITY \\ There where it smells of shit \\ it smells of being \\ man could just as well not have shat, \\ not have opened the anal pouch \\ but he chose to shit \\ as he would have chosen to live \\ instead of consenting to live dead. \\ Because in order not to make caca \\ he would have to consent \\ not to be, \\ but he could not make up his mind to lose being, \\ that is, to die alive. \\ There is in being \\ something particularly tempting for man \\ and this something is none other than caca.
}

\title{
REMEMBRANCE OR TRADITION AS NOISE
}

Repression of what is familiar, which is often avoided, can be extended to an aesthetic level, especially when synthesized by the ideas of contradiction and remembrance. Contradiction binds to instability. It pits positive against negative, true against false, introducing a driving force that propels objective and subjective transformations of knowledge and culture. Contradiction lies at the heart of the action of noise, which, in its dialectical nature, operates sometimes positively (that which promotes, encourages), sometimes negatively (that which annoys, disturbs), depending on the context in which it is found. If contradiction operates according to tension, tradition is based on the retrieval of what has become familiar. For Adorno (1980 [1959], 262), the aesthetic tradition can function almost as a remembrance of something repressed, a kind of repressed anguish. In this case, tradition arises as the familiar which often one wants to avoid.

The criticism that Adorno makes of dodecaphonism, for taking the demands of autonomy in music pieces to the extreme, is an example of the way by which some artists, in an attempt to confront tradition, radically suppress unwanted information. Perhaps, in this movement of rejection against the accepted lies an interesting fact: The repressed tradition takes on a noisy character. In avant-garde movements, in which the new plays a key role, tradition operates as a contradictory force. While summarizing something more disturbing, it promotes the remembrance of practices repressed by the imposition of the "new." 
In Civilization and Its Discontents, Freud (2010 [1930]) considers the repressed as a part of civilization, as a process inherent to social dynamics, as a sort of driving force of society linked to the remembrance of facts that have been repressed throughout history for several reasons. Tradition is a way to bring up to light, that is, to the conscience, something that has been repressed. As Brazilian philosopher Vladimir Safatle says:

In other words, the history of civilization itself is, to some extent, inseparable from something that in the course of a long process can only be assumed, without ever being totally exposed. Something that is internal to it, a mismatch that should be remembered within its tradition. Something that is not a merely external principle. (Safatle 2010, 3)

The process of listening to music is directly related to a trip down memory lane. Listening requires the existence of a match between what is recognized (familiar) and the unknown (strange, new). In this game, crucial to the nature of music, tradition serves as a remembrance mechanism, retrieving the listener's history.

Jorge Luis Borges (1944 [2007]) wrote a short story in which a guy cannot forget anything and, thus, is not able to think. Thinking is generalizing, abstracting, forgetting. Funes, the memorious depicts the story of a young Uruguayan man from the countryside who, after an accident, has a perfect memory. He could accurately remember the color of the clouds at the time when a specific event took place. He could remember in details the shape of the branches of a tree on a windy day. He could recall with total precision a whole day in his life. Nevertheless, for this to happen, he needed a whole day.

Ireneo was nineteen years old; he was born in 1868; he seemed to me as monumental as bronze, older than Egypt, prior to prophecies and pyramids. I thought that each of my words (each of my gestures) would linger on in his ruthless memory; the fear of multiplying useless mannerisms benumbed me. (Borges 1944 [2007], 97)

His extraordinary ability, however, did not allow him to focus on a single memory for a moment and look into it, comparing it against others. Borges, in creating this character, showed how the utmost accuracy and abundance of his memory that prevented him from forgetting any detail also prevented him, exactly for this reason, from generalizing and, therefore, thinking. To think, Borges says, one has to forget and then be able to generalize.

He had effortlessly learned English, French, Portuguese, Latin. I suspect, however, that he was not very capable of thinking. Thinking is to forget differences, to generalize, and to make abstractions. In the filled-up world of Funes, there were only details, mostly immediate ones. (Borges 1944 [2007], 97)

Totalities and generalizations are always present, because thinking operates through some kind of synthesis. That is, in this remembering and forgetting game, there is a mechanism similar to the force that moves and constitutes the social dynamics or artistic transformations. Remembering is required in this game, but it always depends on oblivion, so that recollections can resurface as something new. 


\section{DIALECTICS OF NOISE OR THE PARADOX OF ARTISTIC TRANSGRESSIONS}

Adorno (1988 [1970]), in different passages of his Aesthetic Theory, refers to the dialectical relationship of artistic transgressions, especially concerning the whole process of incorporation of what was previously wrong, not accepted as something necessary for the transformation process of art. About the trivialization of the new, Adorno is assertive:

The abstract New may stagnate, becoming <always the same>. Fetishization expresses the paradox of the entire art, which is not evident for itself, the paradox that what is <achieved> must be done by itself; and, precisely, this paradox is the vital nerve of modern art. The New is necessarily something desired, but, as the Other, it is something <undesired>. Velleity (illusion, dream, hardly achievable, whim) is chained to the always identical, hence the communication between modernness and myth. It aims at non-identity; nonetheless, it becomes identical because of intention; modern art actualizes the anecdotes of Baron Münchhausen: the identification of the non-identical. (Adorno 1988 [1970], 35)

Western music, in its concert tradition, established that noise is precisely what is most primal and visceral to people's actions, what is possibly the very origin of music: screaming, dancing, singing in association with vital actions such as working, celebrating, lamenting. This was done not by suppressing these elements, but by sublimating them. The libidinal energy of these forces is aestheticized and channeled to the production and appreciation of artistic works that move from an experience level to a contemplative level. This shift occurs in different ways. Simon Emmerson (2001), for example, stresses the confinement of some actions that are indirectly referred to in music. La mer becomes "La mer" and a dance becomes "dance." By placing part of our experiences in quotes, concert music promotes a relaxation of what we cannot avoid because it is ingrained in our essence. The dance of our bodies becomes the saraband that does not invite movement, but only contemplation during a concert. At the same time, our voice is prevented from singing and screaming by melodies that are so spectacular that they resist the natural flow of our breath and the tessitura of our vocal organ. The repertoire of a concert signals how much it is necessary to remember these strange noises that are a part of our most intimate desires, because arias, symphonies and concertos refer to them. But this reference is always metaphorical and far off, keeping us connected to what is familiar to us, while concomitantly protecting us from it.

When the death drive brings up this libidinal energy, it overflows within the artistic work, disturbing us and, at the same time, moving us. That is the way the Rite of Spring imposed itself in 1913 as a nonmusical, disturbing rite with its primitive rhythms that possibly moved its listeners beyond contemplation and towards the movement of their bodies propelled to sacrifice. That is how Varèse's strident chords brought back to the ear the vivid and disturbing roughness that the concert hall strived to avoid. In other words, that which in life is familiar and recurrent, and exactly for this reason is disturbing, no matter how much it is avoided (repressed) in music, insists on returning in the form of noise. And even if it does not, its existence, the mere possibility of its return, serves as springboard for creation.

In a sense, this is what American experimental avant-garde works seek by reintroducing what had become noise in music: randomness, lack of control, improvisation. If on the surface this is posed as a reaction to European formalism, in essence it represents the return of libidinal energy into music. One of the mechanisms of this process is a shift from the focus 
on composition (in the sense of conceiving music) to performance (in the sense of making music). Graphical score sheets, vague instructions and other strategies work as a stimulus for reusing actions and the will of the performers as well as (to a lesser extent) that of the audience. The purpose was simply to recover what concert music repressed through a remarkable strategy: becoming an activity closed in itself, a maximum example of autonomous art, whose relationship with nature takes place through representation rather than action.

By pursuing this parallel with psychoanalysis, I have the possibility to study the mechanism that turns noisy, uncomfortable, and sometimes destructive information into the key to escaping from conservative inertia, setting in motion the spring that propels cultural dynamics. Such dynamics, posed as a process of incorporating something "undesirable," although denoting a paradox, is an essential operation in the transformation process of music, establishing itself as a driving energy that adds complexity to music and turns instability into something new. On one hand, noise is negation (a defect), "a resistance, but also defined by what society resists" (Hegarty 2008, ix). On the other, it is also what indicates movement and existence-in short, life.

\section{NOTES}

1. I would like to thank psychoanalyst lara Czeresnia for the fruitful discussions on the topic and for the suggested literature; I would also like to thank Fernando lazzetta for the careful reading and suggestions.

2. According to Laplanche and Pontalis (1988), repression relates to the "operation by which an individual seeks to repel or keep in the unconscious representations (thoughts, images, memories) linked to a drive. Repression is produced in cases where the satisfaction of a drive-likely to provide pleasure by itself-threatens to cause displeasure regarding other requirements." (553). It can be understood as a defense mechanism that makes instinctual requirements, behaviors and attitudes move from the conscious to the unconscious.

3. One can think that the dialectics of noise is more directly linked to the distinction established by Freud between Totem and Taboo than to the connection to repression and death drive. However, the death drive may initially help us investigate the process of desire sublimation and its connection with making art.

4. In the text "Dialectics of Noise" (Campesato 2010), I refer to the dialectics of noise as a problematization process which music undergoes, "whence we resort to noise as an element of destabilization and displacement of functions. For this reason, this noise is musicalized (becomes music) and becomes the background to the emergence of new problematization. This recurrent process can be understood as an element that propels the musical language, incorporating elements of instability to create new stabilities."

5. Pour en finir avec le jugement de dieu was recorded between November 1947 and January 16, 1948 in Paris, for the Office de Radiodiffusion Télévision Française (ORTF). A version performed by Roger Blin can be accessed at: http://www.ubuweb.com/sound/artaud.html. 


\section{REFERENCES}

Adorno, Theodor. 1980 [1959]. "Ideias para a sociologia da música". In Textos escolhidos de Benjamin, Adorno, Horkheimer, Habermas, 259-268. São Paulo: Abril Cultural.

Adorno, Theodor. 1988 [1970]. Teoria Estética. São Paulo: Martin Fontes.

Artaud, Antonin. 1947. "La recherche de la fécalité" (performed by Roger Blin). Pour finir avec le jugement de dieu. http://www.ubuweb.com/sound/artaud.html.

Artaud, Antonin. 1988. Antonin Artaud: Selected Writings. Edited by Susan Sontag. Berkeley: University of California Press.

Borges, Jorge Luis. 1944 [2007]. "Funes, el memorioso." In Ficciones, 117-128. Buenos Aires: Emecé Editores.

Campesato, Lílian (2010). "Dialética do Ruído". In Proceedings of the XX Congresso da Associação Nacional de Pesquisa e Pós-Graduação em Música, 1389-1393. Florianópolis.

Delouya, Daniel. 1998. "Tôpica, o negativo da depressão originária." Revista Percurso, 21. http://www2. uol.com.br/percurso/main/pcs21/artigo2105.htm.

Emmerson, Simon. 2001. "From Dance! to 'Dance': Distance and Digits." Computer Music Journal 25(1): 13-20.

Freud, Sigmund. 2011. "O eu e o id". In Obras completas vol. XVI. O eu e o id, "autobiografia" e outros textos (1923-1925), 9-64. Translated by Paulo César de Souza. São Paulo: Companhia das Letras.

Freud, Sigmund, and Joseph Breuer. 1988 [1893]. "Sobre o mecanismo psíquico dos fenômenos histéricos: comunicação preliminar". In Obras Psicológicas Completas de Sigmund Freud. Vol. II, 37-53. Rio de Janeiro: Imago.

Freud, Sigmund. 2006 [1910]. "Cinco Lições de Psicanálise, Leonardo da Vinci e outros trabalhos". In Obras Psicológicas Completas de Sigmund Freud. Vol. XI, 13-51. Rio de Janeiro: Imago.

Freud, Sigmund. 1988 [1894]. "As Neuropsicoses de Defesa." In Obras Psicológicas Completas de Sigmund Freud. Vol. III, 53-77. Rio de Janeiro: Imago.

Freud, Sigmund. 2010 [1930]. "O Mal-Estar na Civilização". In Obras completas. Vol. XVII, 13-122. Translated by Paulo César de Souza. São Paulo: Companhia das Letras.

Fuks, Betty Bernardo. 2001. "Notas Sobre o Conceito de Angústia". Estudos e Pesquisas em Psicologia 1(1). http://www.revispsi.uerj.br/v1n1/artigos/artigo1.html.

Garcia-Roza, Luiz Alfredo. 2004 [1990]. O Mal Radical em Freud. Rio de Janeiro: Jorge Zahar.

Hegarty, Paul. 2008. Noise/Music: A History. New York: Continuum.

Laplanche, Jean, and Jean-Bertrand Lefebvre Pontalis. 1988. Vocabulário da Psicanálise. São Paulo: Martins Fontes.

Safatle, Vladimir. 2010. Políticas da Forma: Aula 5. Manuscript.

Stiegler, Bernard. 2007. Reflexões (Não) Contemporâneas. Translated by Maria Beatriz de Medeiros. Chapecó: Argos. 